\title{
Standards for the Diagnosis of Concrete Structures using the Non-destructive Test in South Korea
}

\author{
Seonguk Hong, Seunghun Kim, Hyeyoung Kim, Chanwoo Park
}

\begin{abstract}
As there is a lack of studies on the standards related to safety diagnosis methods for concrete structures and current status of diagnosis standards using the nondestructive test in developed nations, this study aims to compare concrete structure diagnosis standards specifically based on the nondestructive test, identify problems, and propose a direction for improvement. To compare and analyze the domestic and overseas safety diagnosis standards for concrete structures, identify problems in the concrete structure diagnosis standards of Korea, and propose directions for improvement.
\end{abstract}

Keywords: Concrete structure, Diagnosis, Non-destructive test, Standards

\section{INTRODUCTION}

In South Korea, numerous concrete structures were constructed along with the rapid urban development after the high-degree economic growth in 1970s, and there is a high ratio of deteriorated structures that were built over 30 years ago. In August 2016, a commercial building that was completed 44 years ago in Jinju, Korea had a roof-collapsing accident in the middle of remodeling. As rebar and concrete sustaining weight of the entire building were deteriorated, walls of this four-floor building collapsed and caused destruction of an assembly panel on the rooftop, resulting in casualties. In September of the same year, a parking lot building was collapsed at a construction site in Tel Aviv, Israel and resulted in casualties. Two months before the collapse accident, this construction site had another accident involving collapse of concrete beam in July. In February 2014, Mauna Resort in Gyeongju, Korea caused about 100 casualties when its roof was collapsed by heavy snow. In the same month, 7-floor studio buildings under construction in Asan, Chungcheongnam-do were 10 days before completion. One of the buildings was slanted to the south by about 20 degrees, and the other building suffered subsidence of the first-floor columns which caused the parking space to disappear. In the case of deteriorated structures, such accidents can be prevented through accurate diagnosis of

Revised Manuscript Received on July 22, 2019

Seonguk Hong, Dept. of Architectural Engineering, Hanbat National University, Daejeon, Republic of Korea. Email: suhong7@ hanbat.ac.kr

Seunghun Kim, Dept. of Architectural Engineering, Hanbat National University, Daejeon, Republic of Korea. Email: kimsh@hanbat.ac.kr

Hyeyoung Kim, Dept. of Architectural Engineering, Hanbat National University, Daejeon, Republic of Korea. Email: 2749222@ naver.com

Chanwoo Park, Dept. of Architectural Engineering, Hanbat National University, Daejeon, Republic of Korea. Email: wannube@naver.com structures. Newly built structures can prevent accidents by estimating compressive strength according to curing of concrete. In addition, there are increasing safety concerns related to structures due to the recent earthquakes that occurred in Pohang and Gyeongju, increasing the interest in diagnosis methods to evaluate status of structures.

Most structures are composed of concrete materials, and concrete is not only used in ordinary structures but also widely applied to special, large-sized structures such as nuclear power plants and military structures. Concrete can be said to have an absolute impact on safety of structures. However, when testing concrete structures, quality changes from conditions and methods of construction and damaging from the environment and external force during use after construction cannot be avoided. Therefore, when evaluating status of structures, it is necessary to manage quality during construction and diagnose them using various techniques during maintenance after construction. Accordingly, there is a popular trend of using the nondestructive test to examine status of structures without damaging or destroying the target structures [1]. The purpose of this study is to compare and analyze the domestic and overseas safety diagnosis standards for concrete structures based on the nondestructive test, identify problems in the concrete structure diagnosis standards of Korea, and propose directions for improvement.

Safety diagnosis refers to an act of investigating, measuring and evaluating structure safety and defects and presenting methods of repair or reinforcement, intended to discover physical and functional defects in structures and take prompt and appropriate measures. Looking at existing studies on problems of structure safety diagnosis and improvement methods, identified non-technical problems by conducting a survey on safety diagnosis institutions and presented a practical improvement method based on the survey results [2]. Derived problems in precise inspection items and detailed items and presented improvement methods [3]. Investigated facilities subject to inspection and industrial status to define detailed criteria, find distribution of evaluation scores and present improvement methods [4]. Selected 10 structures aged 10 years or above to find out problems and improvement methods based on evaluation of reports, inspection history on the Facility Management System, and repair and reinforcement history [5]. 
Proposed the necessity of safety diagnosis based on practice and literature review, analyzed different crack types and causes in structures through the nondestructive test, and examined reliability of the estimating equation [6]. Investigated actual conditions of small and medium-scale remodeling works to propose the necessity of pre-construction safety diagnosis and expert training [7]. As there is a lack of studies [8-16] on the standards related to safety diagnosis methods for concrete structures and current status of diagnosis standards using the nondestructive test in developed nations, this study aims to compare concrete structure diagnosis standards specifically based on the nondestructive test, identify problems, and propose a direction for improvement.

\section{POLICY TRENDS RELATED TO BUILDING ASSESSMENT OF DOMESTIC AND FOREIGN}

\section{A. Republic of Korea}

Laws that regulate general standards for structure including land are the Building Act, Housing Act, and Special Act on the Safety Control. Among them, regulations related to safety inspection can largely be divided into the Construction Technology Promotion Act and Special Act on the Safety Control of Public Structures.

After the collapse of Seongsudaegyo Bridge, the interest in safety management of public structures was increased. The Special Act on the Safety Control of Public Structures was enacted to prevent calamities and disasters through safety inspection and maintenance, enhance the utility of public structures, and secure public safety. This law regulates safety inspection, precise safety diagnosis, safety measures, maintenance of public structures and Korea Infrastructure Safety and Technology Corporation. The law defines that the frequency of inspections is to be as necessary for emergency inspection, at least once in six months for regular inspection, at least once in two years for precise inspection and at least once in five years for precise safety diagnosis. Structures under special management are defined by investigating small or medium-sized public structures that were built over 10 years ago. They are reclassified into three types of public structures to perform regular precise safety diagnosis through specialized companies.

However, the Special Act on the Safety Control of Public Structures focuses on inspection of structural safety and only applies to large-sized public structures and communal structures, neglecting safety and maintenance of any other structures. Also, the Construction Technology Management Act simply reinforces regulation on construction supervision and fails to come up with measures for safety and maintenance of structures. In relation to safety and maintenance of structures, each institution is creating and utilizing its own information system according to individual laws. Therefore, there needs to be an integrated law related to structure safety systems to support public and private systems and practice safety diagnosis and inspection on structures.

\section{B. United states of America}

According to the government structure of the United States and regulation systems of each local government, local governments are operating their own laws related to construction. Public contract laws related to construction services are applied differently according to the ordering body such as the federal government, state governments and local governments. Different states come up with their own laws about regional construction planning. The International Building Code has been implemented as an attempt to combine building standards of the United States, and IBC is used as a model for building laws of each local government. The IBC is a regulation on safety and maintenance of buildings and can be classified into the IEBC (International Existing Building Code) which supplements the IBC in relation to change of usage, extension, remodeling and repair of existing buildings, the ICCPC (International Code Council Performance Code) which suggests water and infrastructure usage to secure safety of building residents, protection of buildings and welfare of communities, and the IPMC (International Property Maintenance Code) which explains terms and requirements for improvement and maintenance of real estate properties. Safety management is performed in accordance with the National Inspection Standard that is generally regulated by disaster regulation laws. Although the frequency of ordinary inspection is defined as once a year, each state government can flexibly adjust it under special circumstances. Also, safety grades are divided into four levels.

\section{United Kingdom}

The building law of England was first created as the necessity of building regulation was posed after the Great Fire of London in February 1666. It was reorganized by ordinances of each local autonomous entities afterwards, but there were problems in the application of the Public Health Act. The Building Act (1984) was enacted by keeping the portion of the existing law on building management and summarizing all laws related to construction and design. The Act has been amended with 13 approved documents and 1,985 regulations. In addition to the Act, a type of law directly enacted by the Parliament which is the highest legislative body of England, ministers, government institutions, Privy Council and the King or Queen, judicial authorities, local autonomous entities and various organizations such as administrative institutions are granted with an authority to enact laws according to Parliamentary Acts. There are many delegated legislations in different names like regulations, rules, orders, schemes, by-laws, licenses, directions, warrants and minutes enacted in relation to structures, all prepared based on the Building Act. The amount of such delegated legislations has dominated the Act enacted by the Parliament. Further, there are laws established directly based on the powers of the King or Queen regardless of Parliamentary Acts. Names of these laws are different, and their legal effects differ as well. There are no special legal restrictions and conditions related to diagnosis of structures, but safety and inspection regulations are defined by the Building Act of 1984 and inspection and maintenance are regulated in the Construction (Design and Management) Regulations of 2007. 
England has a custom of maintaining traditions, and this is also shown by maintenance of structures. Accordingly, as technologies for diagnosis, repair and reinforcement of structures were developed early on in England, standardization of diagnosis in developed nations was mainly driven by England and the United States. Although there are no special restrictions and conditions in relation to diagnosis of structures, the methods of diagnosis, repair and reinforcement are presented according to diagnosis request from universities, construction companies and laboratories. Diagnosis, assessment, repair and reinforcement of structures have been generalized by establishing a regular testing and inspection system. In addition, diagnosis is one of tools to solve problems of structures in England, where diagnosis is habitually used at construction sites.

\section{Japan}

Structure safety management and inspection regulations of Japan are extremely similar to Korea, but safety inspection regulations slightly differ among facilities as they are presented as manuals of relevant institutions. In the case of structures, the Building Standards Act presents guidelines for safety management inspection through the technical guideline for reinforced concrete structures, technical standards for the preservation of state institution structures, and common specifications for the preservation of buildings. The Building Standards Act is the basic building law of Japan that defines the minimal standards for usage such as site and structure, specifies that building managers or occupants are obliged to always maintain building sites and structures legally, and requires safety and maintenance. According to Article 12, paragraphs 2 and 4 of the Building Standards Act, heads of state institutions who manage government structures of the nation, prefectures or city halls with district surveyors are obliged to regularly inspect damaging, corrosion and deterioration of building sites and structures through qualified professionals such as first-class architects and special structure surveyors. Also, Article 5, paragraphs 2 and 3 and Article 5-2, paragraph 1 present tables of inspection yields, methods and results. Regular survey and regular inspection are performed using the methods regulated in Article 5, paragraph 2 and Article 5-2, paragraph 1. In addition, according to the regulation, inspection of structure is to be carried out once every three years and inspection of construction facilities is carried out once every year. Also, Article 16 of the Building Standards Act designates buildings that are required to submit regular reports. Article 100 of the same Act regulates punishments related to inspection. As safety problems have come to the fore as social issues with recent remodeling of deteriorated structures, Japan is amending its construction laws by implementing a more specific and reinforced regular reporting system to increase the effectiveness of safety management and maintenance.

\section{STANDARS OF NONDESTRUCTIVE TEST METHOD FOR CONCRETE STRUCTURES}

\section{A. Republic of Korea}

There are several types of nondestructive test methods used in Korea, including the rebound hardness method (Schmidt hammer), ultrasonic pulse velocity method, core test, pullout test method, and surface wave method. However, the testing method for rebound number to conclude compressive strength of concrete (KS F 2730) and the testing method for velocity of ultrasonic pulses to conclude compressive strength of concrete (KS F 2731) are the only two methods regulated in KS. Source technologies for safety diagnosis using the nondestructive test methods are highly dependent upon developed nations.

\section{B. United states of America}

Structure safety laws and regulations of the United States are different from other nations. Whereas most nations generally apply a single standard established by the central government, the federal government, state governments and local governments enact and execute standards with minimal influence in the United States. They are mainly driven by the private sector. As individual standards are used in the United States, they have an excellent ability to respond to the advancement or change of test methods. ACI 228.2R (Nondestructive Test Methods for Evaluation of Concrete in Structure) of the American Concrete Institute is one of important standards related to the nondestructive test and measurement that defines the nondestructive test methods for evaluation of concrete structures.

Table- I: Standards of nondestructive test method in United States of America

\begin{tabular}{|c|c|c|}
\hline Test Method & Standard & Application \\
\hline Impact Echo Method & ASTM C1383-15 [17] & $\begin{array}{c}\text { Crack } \\
\text { Honeycomb } \\
\text { Void } \\
\text { Depth }\end{array}$ \\
\hline $\begin{array}{c}\text { Slab Impulse } \\
\text { Response Method }\end{array}$ & ACI 228.2R-13 [18] & $\begin{array}{c}\text { Crack } \\
\text { Slab } \\
\text { Tunnel lining } \\
\text { Void }\end{array}$ \\
\hline $\begin{array}{c}\text { Ultrasonic Pulse } \\
\text { Velocity Method }\end{array}$ & ASTM C597-16 [19] & $\begin{array}{c}\text { Compressive } \\
\text { strength of concrete } \\
\text { Homogeneity } \\
\text { Quality evaluation }\end{array}$ \\
\hline $\begin{array}{c}\text { Spectral Analysis of } \\
\text { Surface Waves } \\
\text { Method }\end{array}$ & ACI 228.2R-13 & $\begin{array}{c}\text { Depth of concrete } \\
\text { Ultrasonic Echo }\end{array}$ \\
\hline ACI 228.2R-13 & $\begin{array}{c}\text { Quality of concrete } \\
\text { Compressive } \\
\text { strength of concrete } \\
\text { Crack }\end{array}$ \\
\hline
\end{tabular}

ASTM: American Society of Testing Materials

ACI: American Concrete Institute

It presents a variety of test methods such as visual test, stress wave test and measurement of infrared thermal image. The report helps assess conditions of concrete structures by explaining advantages and limitations of each method. There are other standards like ASTM C1383 (Impact Echo Method) and ASTM C856 (Petrographic Examination). As shown in Table- I summarizes the representative methods defined in the nondestructive test standards in the United States and their characteristic. 


\section{United Kingdom}

Concrete-related standards in England are mainly about testing of hardened concrete. BS 1881 Part Series comprehensively defines the test methods for testing concrete. Detailed standards are presented by Parts 201 209 subordinate to BS1881. Among them, the standards for the nondestructive test include BS 1881 Part 201 (Guide to the use of non-destructive methods of the test for hardened concrete), BS 1881 Part 202 (Recommendations for surface hardness testing by rebound hammer), BS 1881 Part 203 (Recommendations for measurement of velocity of ultrasonic pulses in concrete), BS 1881 Part 205 (Recommendations for radiography of concrete) and BS 1881 Part 207 (Recommendations for the assessment of concrete strength by near-to-surface tests). In addition, there are other common European standards such as BS EN 12540 Part 2 (Regulation of rebound count using the nondestructive test), Part 4 (Determination of velocity of ultrasonic pulses) and BS EN 13554 (Non-destructive testing, acoustic emission testing, general principles). Also, the BS 4408 standard summarizes redundant contents related to the nondestructive test methods for concrete. Table- II presents the nondestructive test standards for concrete in England.

Table- II: Standards of nondestructive test method in United Kingdom

\begin{tabular}{|l|c|l|}
\hline Standard & $\begin{array}{l}\text { Detailed } \\
\text { standard }\end{array}$ & \multicolumn{1}{c|}{ Title } \\
\hline \multirow{5}{*}{ Part 201 } & $\begin{array}{l}\text { Guide to the use of non-destructive } \\
\text { methods of the test for hardened } \\
\text { concrete }\end{array}$ \\
\cline { 2 - 3 } & Part 202 & $\begin{array}{l}\text { Recommendations for surface } \\
\text { hardness testing by rebound } \\
\text { hammer }\end{array}$ \\
\cline { 2 - 3 } & Part 203 & $\begin{array}{l}\text { Recommendations for } \\
\text { measurement of velocity of } \\
\text { ultrasonic pulses in concrete }\end{array}$ \\
\cline { 2 - 3 } & Part 205 & $\begin{array}{l}\text { Recommendations for radiography } \\
\text { of concrete }\end{array}$ \\
\cline { 2 - 3 } & Part 207 & $\begin{array}{l}\text { Recommendations for the } \\
\text { assessment of concrete strength by } \\
\text { near-to-surface tests }\end{array}$ \\
\hline \multirow{5}{*}{ BS 4408 } & Part 1 & Cover measuring devices \\
\cline { 2 - 3 } & Part 3 & Gamma radiography of concrete \\
\cline { 2 - 3 } & Part 4 & Surface hardness method \\
\cline { 2 - 3 } & Part 5 & $\begin{array}{l}\text { Measurement of the velocity of } \\
\text { ultrasonic pulses in concrete }\end{array}$ \\
\hline
\end{tabular}

\section{Japan}

Safety diagnosis equipment and technologies were developed in Japan due to restoration of frequent earthquakes and continuous government support. There is an increasing trend of companies specialized in diagnosis of building and structures, as well as construction companies specialized in repair and reinforcement. In addition, universities, companies, construction offices and material testing centers are supporting and performing diagnosis, consistently improving technology and information. The Japanese Ministry of Land, Infrastructure, Transport and Tourism has implemented the nondestructive test for construction businesses and ordering bodies to secure quality of public projects and is developing a new construction method that tests the cavitation phenomenon inside walls using the nondestructive test methods.

Table- III: Standards of nondestructive test method in Japan

\begin{tabular}{|c|l|}
\hline $\begin{array}{c}\text { NDIS } \\
\text { number }\end{array}$ & \multicolumn{1}{c|}{ Standard name } \\
\hline 1401:2009 & $\begin{array}{l}\text { Radiation transmission test method of } \\
\text { concrete structure }\end{array}$ \\
\hline 2426-1: 2009 & $\begin{array}{l}\text { Test method by elastic wave of concrete } \\
\text { structure } \\
\text { "Part 1: Ultrasonic method }\end{array}$ \\
\hline 2426-2: 2009 & $\begin{array}{l}\text { Nondestructive testing of concrete - } \\
\text { elastic wave method } \\
\text { "Part 2: Impact Elastic Wave method }\end{array}$ \\
\hline $2426-3: 2009$ & $\begin{array}{l}\text { Test method by elastic wave of concrete } \\
\text { structure } \\
\text { "Part 3: Impact Acoustics method }\end{array}$ \\
\hline $3428: 2009$ & $\begin{array}{l}\text { Test method for evaluating the disguise } \\
\text { of the surface part of architecture and } \\
\text { civil structure by infrared camera }\end{array}$ \\
\hline
\end{tabular}

In general, the nondestructive test methods used in Japan include the acoustic method using elastic wave, impact echo method, ultrasonic pulse method, macroscopic ultrasonic pulse method, electromagnetic wave method, electron induction method, rebound test hammer method, and self-potential method. In the standards of the Japanese Society for Non-Destructive Inspection (NDIS), the nondestructive test methods for concrete include the ultrasonic pulse method, impact echo method and acoustic method. Various test methods are presented in Table III. NDIS 1401 defines the radiation transmission test method of concrete structure, NDIS 2426-1 is part 1 ultrasonic method of the test method by elastic wave of concrete structure. NDIS 2426-2 is part 2 impact elastic wave method, and NDIS 2426-3 is part 3 impact acoustics method. NDIS 3428 presents the test method for evaluating the disguise of the surface part of architecture and civil structure by infrared camera. In the Japan Industrial Standard, JIS A 155 presents the rebound test method for concrete.

\section{DISCUSSION}

Looking at domestic and overseas laws related to safety diagnosis of concrete structures, there are various laws other than the Building Act that regulate diagnosis, but they are limited to large-sized structures. Due to the lack of institutions and experts specialized in diagnosis using the nondestructive test methods, there are difficulties in developing independent technologies and establishing standards through verification. 
Table- IV: Standards of nondestructive test method for concrete structures

\begin{tabular}{|c|c|c|}
\hline Nation & Test Method & Standard \\
\hline $\begin{array}{l}\text { Republic } \\
\text { of Korea }\end{array}$ & $\begin{array}{l}\text { Surface Hardness by } \\
\text { Rebound Test } \\
\text { Ultrasonic Pulse } \\
\text { Velocity Method (UPV) }\end{array}$ & $\begin{array}{l}\text { KS F } 2730 \\
\text { KS F } 2731\end{array}$ \\
\hline $\begin{array}{l}\text { United } \\
\text { States of } \\
\text { America }\end{array}$ & $\begin{array}{l}\text { Ultrasonic Pulse } \\
\text { Velocity Method (UPV) } \\
\text { Impact Echo Method } \\
\text { (IE) } \\
\text { Spectral Analysis of } \\
\text { Surface Waves-S }\end{array}$ & $\begin{array}{l}\text { ASTM C } \\
\text { 597-02/E494/95 } \\
\text { ASTM C1383-04 } \\
\text { ACI 228.2R }\end{array}$ \\
\hline Japan & $\begin{array}{l}\text { Radiography } \\
\text { Elastic wave } \\
\text { Infrared thermography } \\
\text { Surface Hardness by } \\
\text { Rebound Test }\end{array}$ & $\begin{array}{l}\text { NDIS 1401/2426-1,2,3/ } \\
3428 / 3434 \\
\text { JIS A } 1155\end{array}$ \\
\hline $\begin{array}{l}\text { United } \\
\text { Kingdom }\end{array}$ & $\begin{array}{l}\text { Surface Hardness by } \\
\text { Rebound Test } \\
\text { Gamma-Radiography } \\
\text { Ultrasonic Pulse } \\
\text { Velocity Method (UPV) }\end{array}$ & $\begin{array}{l}\text { BS 1881 Part } \\
\text { 201-203/205/207 } \\
\text { BS 4408 Pt 1/ 2/ 3/ 4/ } 5 \\
\text { BSI 98/105795 }\end{array}$ \\
\hline
\end{tabular}

KS: Korean Industrial Standards

NDIS: Nondestructive Inspection Standard

JIS: Japan Industrial Standard

BSI: British Standards

In the United States, diverse and individual test methods and laws have been standardized, showing an excellent ability to cope with changes in the test methods. Japan is developing diagnosis equipment and technologies with continuous government support and the advancement of earthquake recovery technologies. The test methods are presented by laboratories and companies, and diagnosis and assessment are carried out reasonably by establishing a regular inspection system. Also, Japan is far advanced in terms of application technologies compared to Korea. England is making efforts into maintenance and regular inspection of structures. England tends to solve diagnosis problems by presenting comprehensive measures (repair and reinforcement). As shown in Table IV summarizes the safety diagnosis standards of different countries for concrete buildings based on the nondestructive test methods.

\section{CONCLUSION}

The frequency of accidents is increasing with the increasing number of concrete structures because of inadequate diagnosis, and there is a lack of measures for prevention. In addition, the importance of safety inspection on structures has been increasing with the recent earthquakes. When comparing the diagnosis standards for concrete buildings using the nondestructive test methods with developed nations, Korea is considerably falling behind in terms of nondestructive test standards, often citing and applying foreign standards. With the advancement of IT, diverse nondestructive test methods must be developed. It would be essential to establish diagnosis standards for concrete structures using the nondestructive test methods, enact and verify national laws, and foster professional institutions to promote safety diagnosis of structures that focuses on prevention.

\section{ACKNOWLEDGMENT}

This paper was supported by Basic Science Research Program through the National Research Foundation of Korea (NRF) funded by the Ministry of Education (No.2018R1D1A1B107043472)

\section{REFERENCES}

1. H. Y. Kim, S. U. Hong. "Status of Diagnosis Standards of Concrete Structures Using Nondestructive Test Methods" in Conference Proceeding of Korea Institute for Structural Maintenance and Inspection. Autumn, 2016, pp. 43-44. Available: http://db.korea scholar.com/ article. aspx? code $=317070$

2. J. A. Cho, G. J. Go, C. S. Lee. "Improvement to Problem of Building safety inspection and precise safety diagnostics" in Korea Institute of Construction Management. vol.10, 2015, pp. 122-126.

3. J. B. Lee. "Problem Analysis and Improvements Based on Case Studies on Report of Detailed Building Inspections" Master's Thesis. Chung-Ang University, 2014.

4. B. T. Jeong. "Problem Analysis and Improvements Based on Case Studies on Report of Detailed Building Inspections" Master's Thesis, Chung-Ang University, 2013.

5. M. S. Kim. "Improvement of Reliability in The Evaluation of structural Safety Check for Buildings" Master's Thesis, Incheon University, 2012.

6. S. Y. Hwang. "A Study on the Improvement of Safety Diagnosis in Reinforced Concrete Structures" Master's Thesis, Dongguk University, 2009

7. C. H. Son, S. W. Hong, Y. S. Ahn. "Application of Safety Diagnosis in Small and Medium Scale Remodeling Construction" Journal of Regional Association of Architectural Institute of Korea, vol.9 (1), 2007, pp. 171-178.

8. Y. J. Kim. "A Comparative Legal Study on Construction Safety Legislation in United States of America" Korea Legislation Research Institute. 2015, pp. 1-95.

9. Y. H. Kim. "Nondestructive Testing of Concrete Structure" in Journal of the Korean society for nondestructive testing, vol.20 (4), 2000, pp. 329-341. Available: http://www.dbpia.co.kr/Article/NODE02211109.

10. Y. H. Kim. "A Comparative Legal Study on Construction Safety Legislation in United Kingdom" in Korea Legislation Research Institute, 2015, pp. 1-154.

11. H. B. Kim. "A Study for the Newest Tendency Seizing and Development Object of Nondestructive Inspection and Smart Technology in Concrete Structures" in Daejeon University.

12. H. J. Kim. "A Study on the Problems and Improvement of Building Maintenance and Management Inspection Manual" Master's Thesis. Seoul National University of Science and Technology, 2015.

13. C. J. Na. "A Comparative Legal Study on Construction Safety Legislation in Japan” in Korea Legislation Research Institute, 2015, pp. 1-82.

14. H. J. Yoon. "A Study on Building Maintenance Institutionalization by Comparing with the Foreign Countries' Cases" in Journal of the Korean Society of Civil Engineers, vol.31 (6D), 2011, pp. 857-865.

15. H. J. Yoon. "A Study on the Improvement of Building Maintenance System - Focusing on Comparison with Japanese Case" in Journal of the Korean Society of Civil Engineers, vol.35 (3), 2015, pp. 737-745. Available: DOI: http://dx.doi.org/10.12652/Ksce.2015.35.3.0737.

16. J. Y. Jeon. "Systematization of domestic building maintenance field and Direction for Advancement" in Construction engineering and management, vol. 8 (5), 2007, pp. 19-21.

17. ASTM C 1383-15. "Standard test method for measuring the P-wave speed and the thickness of concrete plates using the impact echo method" in American Society for Testing and Materials, 2015. Avail -able: DOI: 10.1520/C1383-15. https://www.astm.org /Standards/C 1383.htm.

18. ACI 228.2R-13. "Nondestructive test methods for evaluation of concrete in structures" in American Concrete Institute Committee 228, 2013. Available: https://www.concrete.org/Portals/0/Files/PDF/Previews/ 228 213.pdf.

19. ASTM C 597-16. "Standard test method for pulse velocity through concrete" in American Society for Testing and Materials, 2016 Available: DOI: 10.1520/C0597-16. https://www.astm.org/ Standards 


\section{AUTHORS PROFILE}

Seonguk Hong is a Research Professor of Department of Architectural Engineering at the Hanbat National University. He received his Ph.D. from the School of Architectural Engineering at the Hanyang University, Republic of Korea. $\mathrm{He}$ is a chairman of the KCI Committee 402: Structural Assessment. His research interests include structural assessment and nondestructive testing for concrete structures

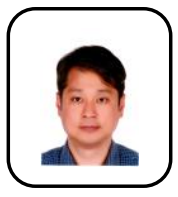

Seunghun Kim is a Professor of Department of Architectural Engineering at the Hanbat National University. He received his Ph.D. in Architectural Engineering at the Hanyang University, Republic of Korea. $\mathrm{He}$ is a vice chairman of the Korea Institute for Structural Maintenance and Inspection. His research interests include composite structure in the field of reinforced concrete structure.

Hyeyoung Kim is a researcher of Department of Architectural Engineering at the Hanbat National University. His research interests include nondestructive testing for concrete structures.

Chanwoo Park is a researcher of Department of Architectural Engineering at the Hanbat National University. His research interests include structural assessment for concrete structures. 